\title{
Fluoride ions in groundwater of the Turkana County, Kenya, East Africa
}

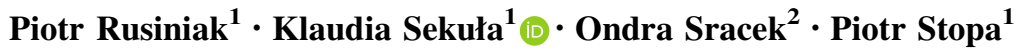

Received: 18 January 2021/Revised: 11 May 2021 / Accepted: 27 May 2021 / Published online: 9 June 2021

(C) The Author(s) 2021

\begin{abstract}
Groundwater samples were evaluated throughout Turkana County (Kenya, East Africa) while looking for drinking water sources. Some samples showed high concentrations of fluoride with values in the range of $0.15-5.87 \mathrm{mg} / \mathrm{L}$. Almost $50 \%$ of the samples exceeded the WHO and Kenyan potable water standard guideline value of $1.5 \mathrm{mg} / \mathrm{L}$ for drinking water quality. The hydrogeochemical studies revealed that the dominant cation in water is $\mathrm{Na}^{+}$and the dominant anion is $\mathrm{HCO}_{3}{ }^{-}$resulting in $\mathrm{Na}-$ $\mathrm{HCO}_{3}$ type of groundwater, followed by $\mathrm{Ca} / \mathrm{Mg}-\mathrm{HCO}_{3}$ or $\mathrm{Na}-\mathrm{SO}_{4}$ and $\mathrm{Na}-\mathrm{Cl}$ in a few cases. Speciation modelling revealed that the groundwater is undersaturated with respect to gypsum and anhydrite, mostly undersaturated with respect to fluorite (6 samples are at equilibrium), and supersaturated or at equilibrium with respect to calcite $\left(\mathrm{CaCO}_{3}\right)$. Precipitation of calcite favours the dissolution of F-rich minerals in the alkaline medium. Simultaneously, groundwater is enriched with sodium and bicarbonate, probably as a result of chemical weathering of Na-feldspar. Investigated groundwater can be presumably used for drinking purposes from 17 wells, but a detailed investigation of other trace element concentrations is necessary.
\end{abstract}

Keywords Africa - Kenya - Fluoride - Groundwater · Drinking water $\cdot$ Speciation calculation

Klaudia Sekuła

klaudia.sekula@agh.edu.pl

1 Department of Hydrogeology and Engineering Geology, Faculty of Geology, Geophysics and Environmental Protection, AGH University of Science and Technology, Mickiewicza 30 Av, 30-059 Kraków, Poland

2 Department of Geology, Faculty of Science, Palacky University Olomouc, 17. listopadu 12, 77146 Olomouc, Czech Republic

\section{Introduction}

Fluorine (F) belongs to the halogen group (17th group in the periodic table), its prevalence in the Earth's crust reaches $0.06 \%-0.09 \%$ and classifies it at the 13th place in terms of occurrence among other elements (Singh et al. 2018). It is one of the important microelements for the human organism, thus its deficiency and also excess are adverse for human health. The range between desired $(0.05-0.07 \mathrm{mg} / \mathrm{kg}$ body weight $)$ and toxic dose $(5 \mathrm{mg} / \mathrm{kg}$ body weight) for fluoride are quite narrow (Fordyce 2011; Ullah et al. 2017). The recommended concentration of fluoride ions in drinking water should not exceed $0.7 \mathrm{mg} / \mathrm{L}$. The reported cases of fluoride poisoning mainly concerned toothpaste, mouth rinses, and supplements (Ullah et al. 2017). In the case of fluorine deficiency, the tooth enamel may not be protected against the sugar acids what can lead to tooth decay (Hsu et al. 2018; Singh et al. 2018). Long exposure to the high concentration of fluorine, above the guideline value $(\mathrm{GV}=1.5 \mathrm{mg} / \mathrm{L})$ recommended by the World Health Organization (2017), can lead to the dental $(0.9-1.2 \mathrm{mg} / \mathrm{L}$ of fluorides supplied with drinking water and dependent on other exposure sources) or skeletal fluorosis (3-6 mg/L of $\mathrm{F}^{-}$in drinking water). Fluoride ions in the human organism can co-precipitate with calcium ions as insoluble $\mathrm{CaF}_{2}$ (fluorite) in the human body leading to hypocalcaemia (Pettifor et al. 1989; Fordyce 2011; Khairnar et al. 2015; Singh et al. 2018).

In water, it occurs predominantly as fluoride ion $\left(\mathrm{F}^{-}\right)$, and its main source is minerals containing fluorine i.e., fluorite $\left(\mathrm{CaF}_{2}\right)$, cryolite $\left(\mathrm{Na}_{3} \mathrm{AlF}_{6}\right)$, fluorapatite $\left[\mathrm{Ca}_{5}(-\right.$ $\left.\mathrm{PO}_{4}\right)_{3} \mathrm{~F}$, and rock phosphate. These minerals are widely used in the glass industry (Deng et al. 2018), as an ingredient of insecticides (Podder et al. 2012), as well as in the future they could be used in biomedicine as bioimaging 
agent (Milojkov et al. 2020). In the Earth's crust under high-temperature conditions, fluorine is more mobile (Ali et al. 2018). The process controlling the presence of fluorine in the environment is chemical weathering of minerals containing this element (natural origin) and anthropogenic activities i.e., application of phosphate fertilizers, dust fall in phosphate industrial area, and fluorine released from coal-burning (Pauwels et al. 2015; Dehbandi et al. 2017; Hong et al. 2018; Singh et al. 2018; Fuge 2019; Wang et al. 2019). In groundwater, the occurrence of fluorine is often linked to the volcanic rocks in crystalline basement aquifers (Ozsvath 2006). It can co-occur with arsenic (AlarcónHerrera 2013; Alarcón-Herrera et al. 2020), and its concentration is controlled by alkalinity, and concentrations of calcium and bicarbonate (Saxena and Ahmed 2001; Ali et al. 2016, 2018). The main mineral source controlling aqueous fluoride geochemistry is the solubility of fluorite (Apambire et al. 1997; Edmunds and Smedley 2004). Moreover, much research indicated a negative correlation between $\mathrm{Ca}$ and $\mathrm{F}$ ions concentration. Furthermore, in waters with a low concentration of calcium ions, there is a strong positive correlation between sodium and fluorine ions. The high concentration of sodium ions increases the solubility of fluorite through the base exchange (Apambire et al. 1997).

The concentration of fluoride can be also sometimes connected with the depth of the borehole. In research published by Nair et al. (1984), a general tendency shows the positive trend between $\mathrm{F}^{-}$concentration and depth in Kenya-the deeper the fluoride concentrations increase and are in the range of $1-5 \mathrm{mg} / \mathrm{L}$. Guo et al. (2012) presented that the depth of the wells (up to $30 \mathrm{~m}$ ) has no impact on the fluoride amount $(0.3-2.57 \mathrm{mg} / \mathrm{L})$ found in the Shahai (Inner Mongolia) groundwater. As well, Ali et al. $(2018,2019 b)$ showed that the variability in fluoride concentration in Western Haryana (up to $19 \mathrm{mg} / \mathrm{L}$ ), Sindh, and Punjab in Pakistan $(0.1-3.9 \mathrm{mg} / \mathrm{L})$ can be explained itself in the depth of the well with a negative correlation of -0.2 . On the other hand, Abdurahman and Zewdie (2018) presented the inversed relationship between $\mathrm{F}^{-}$ concentration $(0.65-4.10 \mathrm{mg} / \mathrm{L})$ and borehole depth (25-250 m).

Fluorine is one of the causes of natural groundwater pollution around the world i.e. in Sweden (Berger et al. 2016a, b), Brazil (Martins et al. 2018), India (Reddy et al. 2010; Mondal et al. 2014; Pauwels et al. 2015; Kumar et al. 2017, 2018; Raju 2017; Raj and Shaji 2017; Ali et al. 2018, 2019a; Gupta and Misra 2018; Laxmankumar et al. 2019; Kanagaraj and Elango 2019; Yadav et al. 2019a, b), Ghana (Craig et al. 2018; Zango et al. 2019), China (Hu et al. 2013; Zhang et al. 2017; Wu et al. 2018; Su et al. 2019), Pakistan (Rafique et al. 2015; Rashid et al. 2018; Ali et al. 2019b), Iran (Dehbandi et al. 2018; Enalou et al.
2018; Naderi et al. 2020), South Korea (Chae et al. 2007). In poor and developing countries, where there is a hardship with access to pure drinking water and the problem of fluorine groundwater pollution has also been encountered, e.g., in Nigeria (Emenike et al. 2018), Namibia (Sracek et al. 2015; Abiye et al. 2018;), Kenya (Gaciri and Davies 1993; Zevenbergen et al. 1996; Olaka et al. 2016), Ethiopia (Tekle-Haimanot et al. 2006; Rango et al. 2010, 2012, 2014, 2017; Kravchenko et al. 2014; Colombani et al. 2018), and Malawi (Msonda et al. 2007). To summarise, the general mechanism controlling the high concentration of $\mathrm{F}^{-}$ions in groundwater has geogenic sources that are: long residence-time favouring water-rock interaction processes, evaporation, hydrogeochemical type changes during water flow (from $\mathrm{Ca}-\mathrm{HCO}_{3}$ to $\mathrm{Na}-\mathrm{HCO}_{3}$ ), weathering or dissolution of F-bearing minerals, geological setting i.e., presence of crystalline basement rocks within the wells or salt-rich geological formations, sorption and ion-exchange processes. The chemical composition of groundwater especially characterised by high concentrations of $\mathrm{HCO}_{3}{ }^{-}$and $\mathrm{Na}^{+}$and alkaline $\mathrm{pH}$ play the most primary role for fluoride releasement to the groundwater. Other factors, usually negligible, that affect the fluoride concentrations are anthropogenic i.e., agricultural activities (groundwater is enriched in $\mathrm{F}^{-}$ions due to the leaching from fertilizers) or mining activity.

This work is focused on the prevalence of fluoride in groundwater from Turkana County, Kenya. In the case of the Kenyan groundwater, the major considerable source of its F-enrichment is a geogenic source and the processes responsible for that phenomena are discussed in this paper. The research is based on the archive's data obtained during looking for water that can serve as a source of drinking water for local communities. The objective is to identify wells with high fluoride concentrations and to determine processes responsible for the fluoride groundwater enrichment.

\section{Local geology, material, and methods}

\subsection{Study area}

Turkana is the largest county situated in the north-western part of Kenya. It covers $77,000 \mathrm{~km}^{2}$ and constitutes about $43 \%$ of the total area of the Rift Valley Province in Kenya. This county includes the endorheic and alkaline $(\mathrm{pH}=9.2)$ Turkana Lake (Fig. 1a) which forms a natural eastern boundary of this region. Turkana is split into 6 districts: Turkana North, Turkana West, Turkana Central, Loima, Turkana East and Turkana South. The study area has semiarid climate conditions based on Köppen classification (Fig. 1b, c). The average annual precipitation and 


\section{Fluoride ions in groundwater of the Turkana County, Kenya, East Africa}

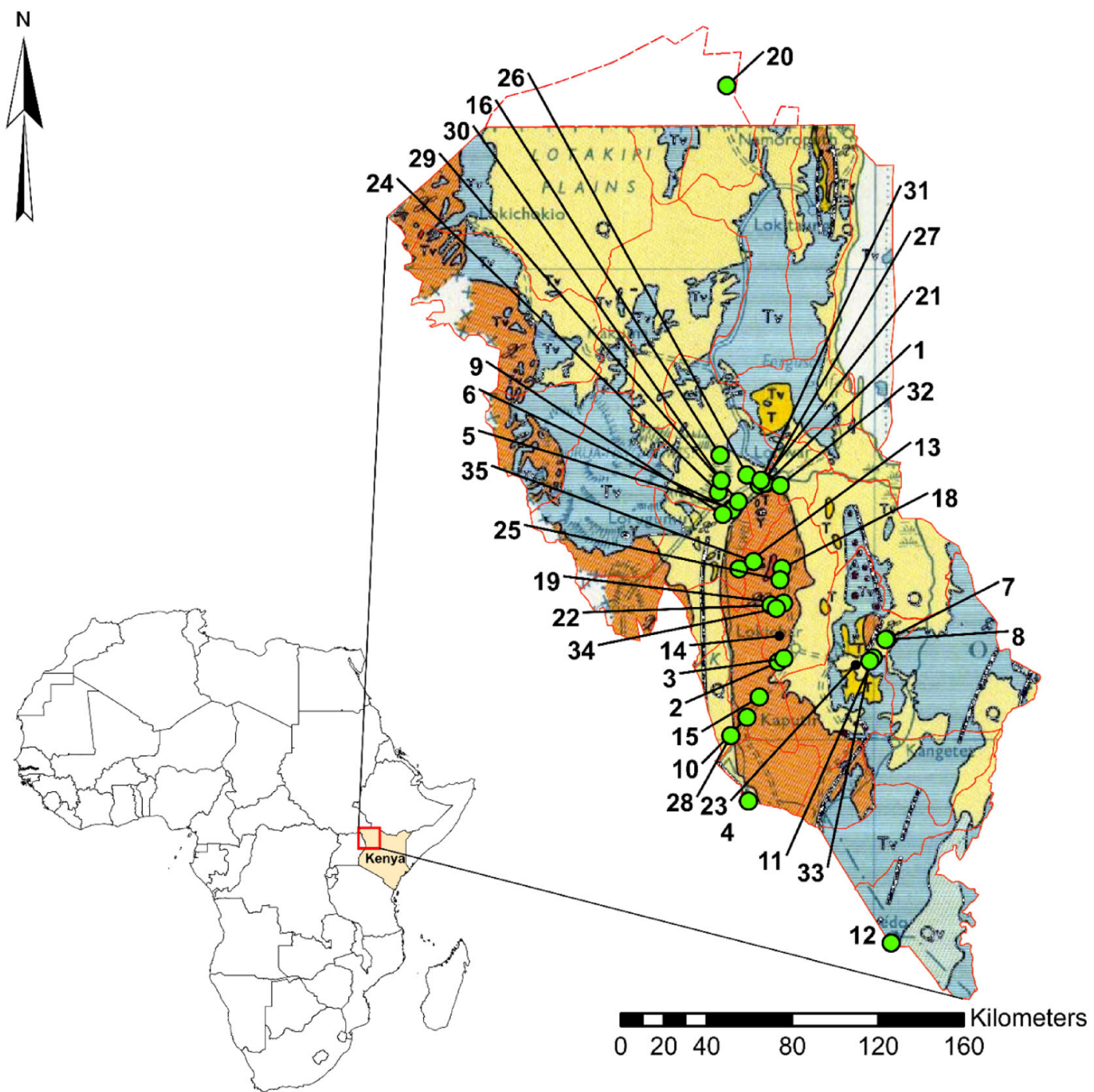

EXPLANATION

\begin{tabular}{|c|l|}
\hline Q & Quaternary Sediments \\
\cline { 1 - 1 } Qv & Quaternary Volcanics \\
\cline { 1 - 1 } Tv & Tertiary Volcanics \\
\cline { 1 - 1 } & Tertiary Sediments \\
\cline { 1 - 1 } T & Cretaceous \\
\hline J & Jurassic \\
\hline Tr & Triassic \\
\cline { 1 - 1 } C-P & Carboniferous?-Permian \\
\hline
\end{tabular}

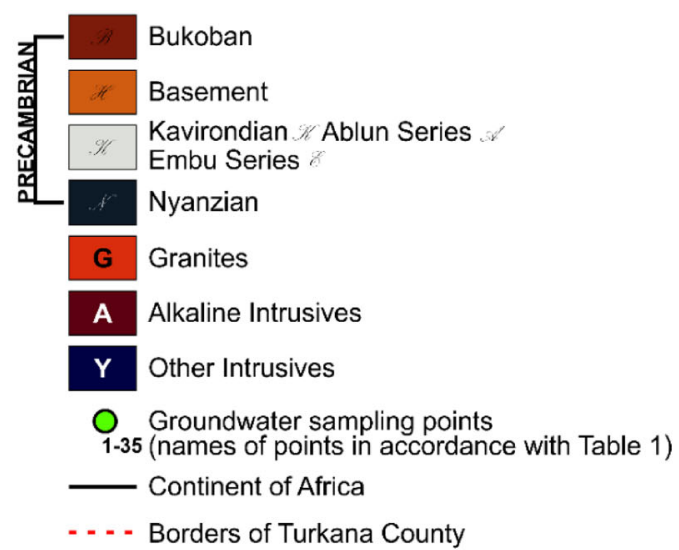

Fig. 1 Geology of Turkana County (Chief Geologist Mines and Geological Department 1962) and sampling points 
temperature in the area are $210 \mathrm{~mm}$ and $29^{\circ} \mathrm{C}$, respectively. It is the poorest region in Kenya with frequent drought and famine problems. One of the major problems besides famines that people face out are droughts that occur every 2-4 years. It implies the water sources dry out, the number of sites with available water decreases, and the epidemics of water-borne diseases among people and animals break out (Oduor et al. 2012). In East Africa, during droughts, the recharge of the groundwater aquifers from the rainfall can be reduced even by $70 \%$ compared to the wet season, therefore the fluctuations in the groundwater table and changes in water quality are highly possible (Ferrer et al. 2019; Ochungo et al. 2020).

\subsection{Geology}

The geological setting of the study area is lithologically and tectonically variable. The oldest formations that can be observed in this area are metamorphized rocks of the Precambrian crystalline basement (Walsh and Dodson 1969). After deposition and deformation of the crystalline basement rocks, there was a stratigraphic gap. Precambrian rocks are covered with unconformable Cretaceous calcareous sedimentary rocks the so-called Turkana Grits, Paleogene-Neogene sedimentary, volcanic sediments, as well as the Quaternary sediments.

It is believed that the crystalline basement was formed from the sequence of the metamorphized sediments, volcanic rocks, and mafic and ultramafic intrusions. These sediments during orogenesis undergone successive compression, regional metamorphism, and injection of granites. As a result, there are gneisses, granulites, migmatites, quartzites and, marbles (Walsh and Dodson 1969). The crystalline basement rocks are observed in most of the geological profiles of the wells studied in this work. There are represented by gneisses with different mineral composition.

The Turkana Grits were firstly dated to the Jurassic age, but subsequent studies suggested periods from Cretaceous to Miocene (Dodson 1971). In studies from the 1960s, including the geological map presented in this work (Fig. 2), Miocene dating was adopted (Chief Geologist Mines and Geological Department 1962). Nowadays, due to the discoveries of dinosaur fossils (Handford 1987), they are now recognized as the Upper Cretaceous deposits. In the vast majority of the study area, the Turkana Grits occur as the calcareous, granular sandstones. These sediments occur in the north-west from the Tertiary volcanites (Tv) on a map marked as Tertiary sediments (T), (Fig. 1).

The Tertiary series of volcanic rocks cover the upper Cretaceous sediments. They form the chain of hills running from the north to south in the eastern part of the study area and on the north from Lodwar city. They are represented by fine crystalline basalts.

The Tertiary sediments include sandstones and shales of fluvial and limnic origin and are dated from the Paleogene to the middle Miocene. They fill the Paleogene Lokichar Basin covering the central and south-eastern part of the area, of the N-S orientation, $60 \mathrm{~km}$ long and $30 \mathrm{~km}$ wide (Tiercelin et al. 2004).

\subsection{Hydrogeology}

From the hydrogeological point of view, five-rock formations are essential for water supply in the Turkana Lake area. In the well profiles, there are alluvial sediments, Turkana Grits, and crystalline basement rocks. Others rocks are olivine basalts and phonolites linked to the Tertiary volcanic activity.

Crystalline basement rocks are characterised by a simple weathering profile. Along with the depth, the degree of weathering profile decreases to unweathered and low permeability rock. Groundwater, if found, usually occurs in the weathering zone close to its base, in local fissure systems and sediments above the basement rock. A good indicator of the likely occurrence of groundwater is the presence of a deep weathering zone and low clay content (Turkana Drilling Consortium 2008).

Lava's flow such as basalts and phonolites very rarely have significant primary porosity. Water usually can be found in the fissure zones, crevices and pyroclastic layers at the contact of different lava flows within the same lithology and so-called Old Land Surfaces. The thickness of such water-bearing horizons is generally limited to few metres (Turkana Drilling Consortium 2010).

The floodplains of the permanent and seasonal rivers are perspective areas for groundwater exploration. Often dried riverbeds are covered with water-bearing sandy alluvium. For Turkana nomads, shallow dug wells in the riverbeds are the most important, basic source of water. The Lokichar Basin located in the central and south-eastern part of the study area is often characterised as having a low potential for finding groundwater, especially with the growing distance from riverbeds (Turkana Drilling Consortium 2008).

\section{Source of data}

This study is based on the archival results of physicochemical analyses performed for 35 points scattered throughout Turkana County from which groundwater was collected in the years 2004-2016. The water-bearing rocks were variable and included volcanic, sedimentary, and metamorphic rocks. The depth of the wells was from 17 to $80 \mathrm{~m}$ below surface level and two water horizons were 

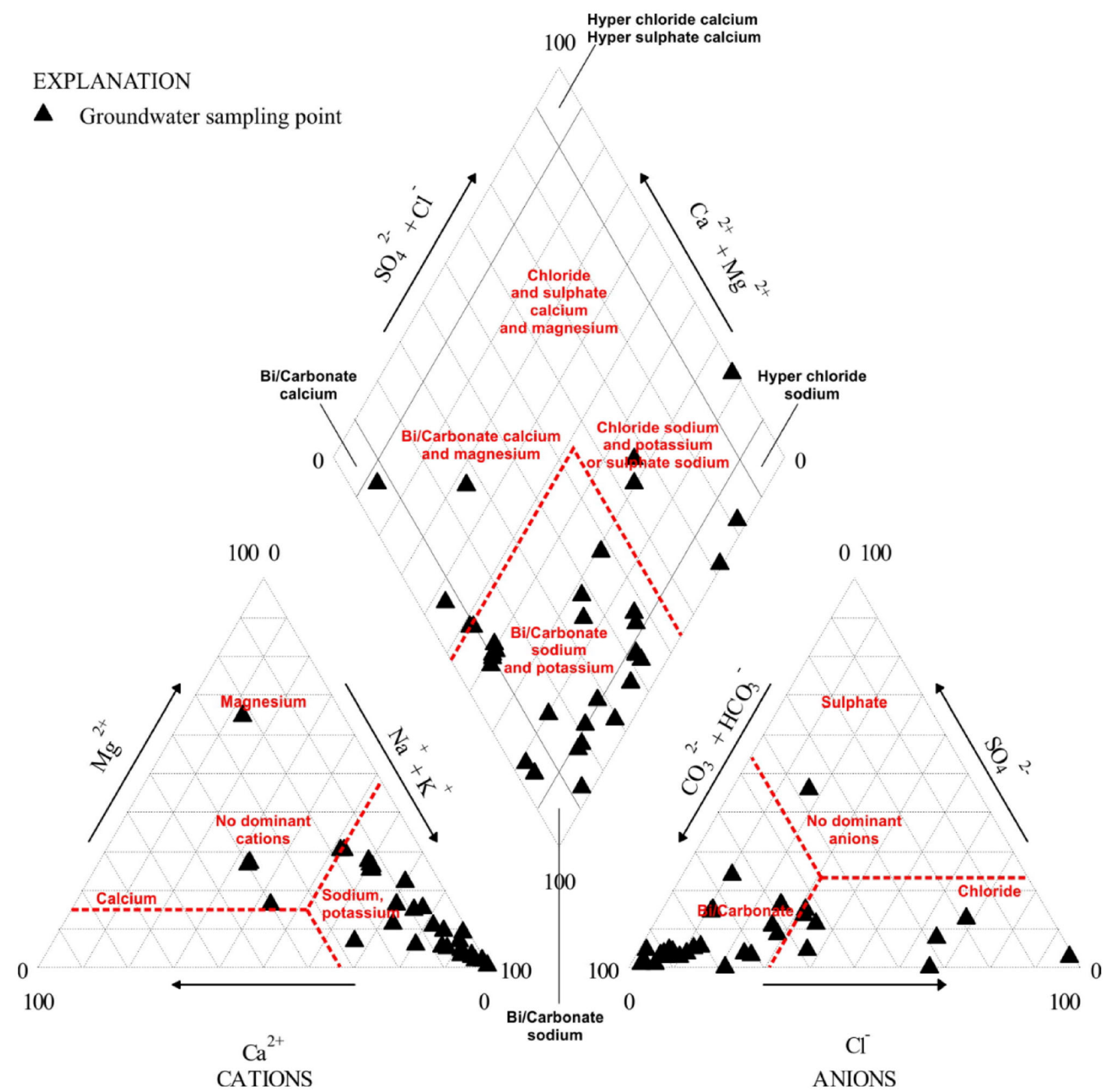

Fig. 2 Hydrogeochemical characteristics of groundwater using the Piper Diagram

recognized. The data used for the research purposes are archived and they were accessed from the Government Chemist's Department of the Republic of Kenya (https:// www.govchemists.go.ke/). The reports of the chemical analyses did not include the methods of analysis therefore the results of chemical analyses were checked by calculation of the charge balance error. All information about wells including the name of the sampling point, coordinates, year, and the results of chemical analysis are given in Table 1.

\section{Results}

\subsection{Water chemistry}

\subsubsection{Hydrogeochemical facies}

The hydrogeochemical characteristics including chemical analyses, calculating the charge balance, the mineralization based on the major ions $\left(\mathrm{Ca}^{2+}, \mathrm{Mg}^{2+}, \mathrm{Na}^{+}, \mathrm{K}^{+}, \mathrm{Cl}^{-}\right.$, 

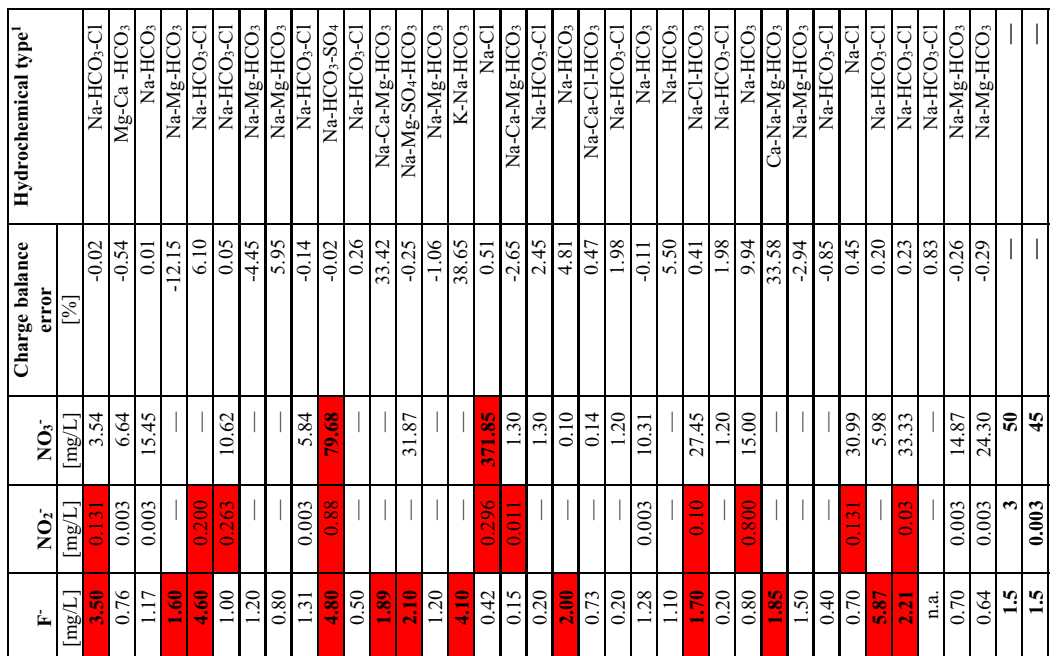

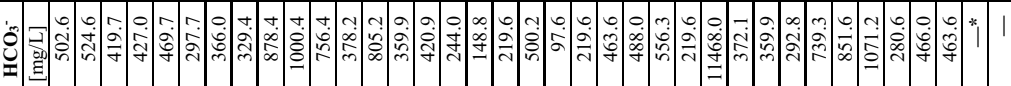

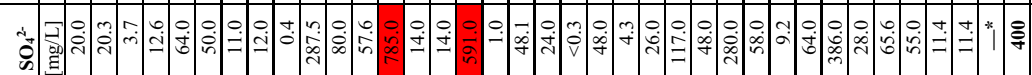

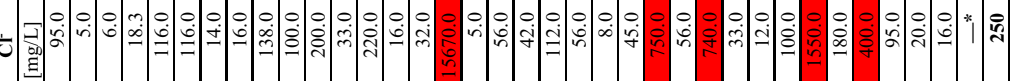

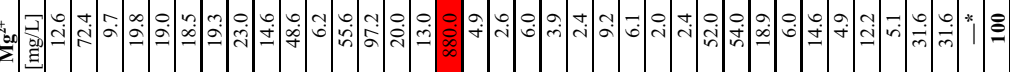

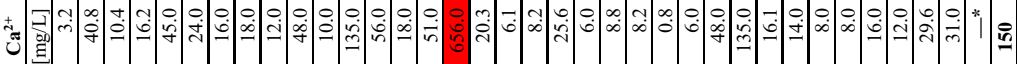

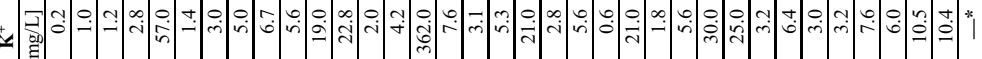

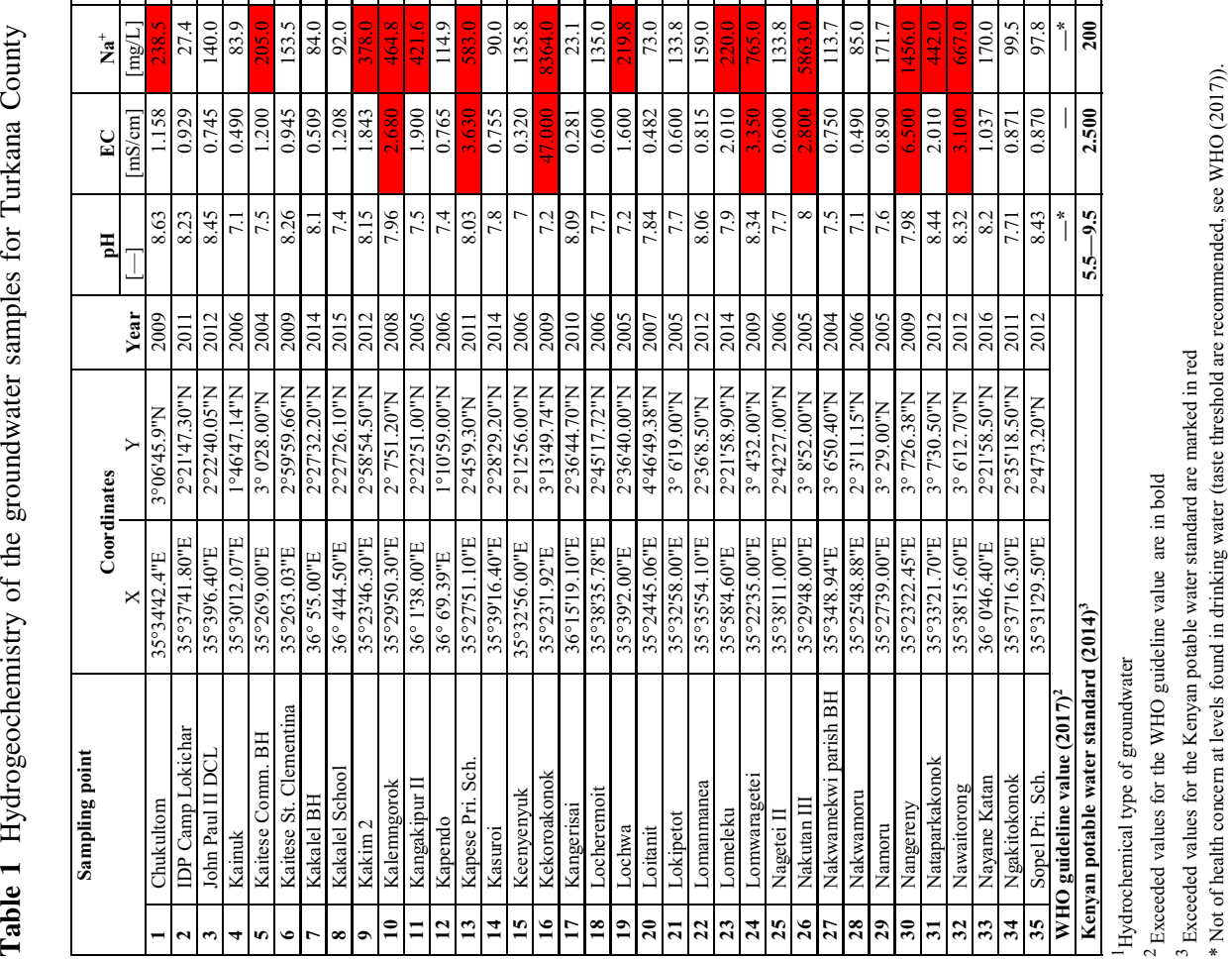


$\mathrm{HCO}_{3}{ }^{-}$and $\mathrm{SO}_{4}{ }^{2-}$ ) and denomination of the hydrochemical type of water.

The charge balance error was calculated for 35 points. For almost all samples charge balance error was acceptable (in range of $\pm 10 \%$ ) except few ones (No. 4, 12, 15, and 27) possibly affected by the analytical methods used, physical parameters interfering with the measurements, and sampling method applied (Mika et al. 2018; Wạtor et al. 2018, 2019; Rusiniak et al. 2020). Despite this, these samples were included in the statistical analysis and speciation modelling - a source of errors generated during sampling and laboratory instrumentation could not be verified based on the documentation and shortened chemical analysis reports gathered. Calculated mineralisation of the groundwater collected varies from 206.2 to $26,413 \mathrm{mg} /$ L. The mineralization (M) is mainly controlled by the concentration of bicarbonates and sodium ions-there is a strong Pearson correlation between $\mathrm{M}$ and $\mathrm{HCO}_{3}{ }^{-}$ $(\mathrm{R}=0.994)$ and $\mathrm{Na}^{+}(\mathrm{R}=0.998)$. Furthermore, there was observed a clear effect of $\mathrm{Cl}^{-}$and $\mathrm{SO}_{4}{ }^{2-}$ concentrations on the groundwater mineralization $(\mathrm{R}=0.714$ and $\mathrm{R}=0.372$, respectively). From these calculations, two sample outliers (saline water) which affected the calculations of correlation coefficient were excluded (No. 16 and 30). The analysed all water samples can be classified in a range from fresh, brackish to saline water based on mineralization parameter. As the Piper Diagram shows, groundwater types in Turkana County (Fig. 2) are mainly $\mathrm{Na}+\mathrm{K}-\mathrm{HCO}_{3}$, Ca-Mg$\mathrm{HCO}_{3}, \mathrm{Na}+\mathrm{K}-\mathrm{Cl}$, or Na-SO .

\subsubsection{Quality of the Turkana County groundwater from viewpoint of human consumption}

To assess the suitability of groundwater collected across Turkana County for drinking purposes, current guidelines and legal regulations were used. The guidelines for drinking water quality published by the World Health Organization (2017) were adopted as the main reference. Additionally, the Kenyan Potable water standard (2014) was used in this assessment.

Among the chemical parameters included in this study, the guideline of WHO specify the maximum allowable concentration values only for fluoride, nitrite, and nitrate. The values specified for these indices are justified by proven real or potentially toxic effects on human health (WHO 2017). In the Kenyan Potable water standards and the EU regulations, there are already established maximum permissible levels for the following physicochemical parameters: magnesium, sodium, chlorides, sulphates, $\mathrm{pH}$ value, electrical conductivity, and also for calcium in the case of Kenyan regulations (Table 1).

Within the analysed parameters, groundwater samples from 17 wells met the requirements established in the guideline and regulations mentioned with the simultaneous absence of data for nitrite and nitrate concentration in 10 samples $\left(\mathrm{NO}_{2}{ }^{-}\right)$and 9 samples $\left(\mathrm{NO}_{3}{ }^{-}\right)$. The concentration of the fluoride was in the range of $0.15-5.87 \mathrm{mg} / \mathrm{L}$. In 12 samples the concentration of $\mathrm{F}^{-}$exceeded the WHO guideline value and the maximum permissible level contained in the Kenyan legislation of $1.5 \mathrm{mg} / \mathrm{L}$. In 22 samples where the $\mathrm{F}^{-}$concentration was below or equal to $1.5 \mathrm{mg} /$ $\mathrm{L}$, the calculated mean and median concentration is 0.77 and $0.75 \mathrm{mg} / \mathrm{L}$, respectively. For higher concentrations the statistical parameters are $3.02 \mathrm{mg} / \mathrm{L}$ (mean) and $2.16 \mathrm{mg} / \mathrm{L}$ (median). Considering the results for the whole region, the mean concentration of $1.56 \mathrm{mg} / \mathrm{L}$ exceeds the guideline value of $1.5 \mathrm{mg} / \mathrm{L}$, while the median suggests that the water is suitable for drinking purposes $(1.19 \mathrm{mg} / \mathrm{L})$. For the Nayane Katan sample, the fluoride concentration was not available.

The regional distribution of the fluoride ion showed no dependence on the borehole depth like in the publication of Abdurahman and Zewdie (2018). Only when the data is divided into subgroups based on the water-bearing formations (sediments, basement, and volcanic rocks), fluoride tend to show a negative correlation with depth in sedimentary rocks (Table 2). For basement and volcanic rocks, there was not found a significant correlation between $\mathrm{F}^{-}$ concentration and the borehole depth.

The fluoride constitutes the main problem in analysed groundwater due to its fairly high concentrations. Concentrations are often much higher than the guideline value led to skeletal fluorosis which is a problem met in Turkana County (Fig. 3).

Analysing subsequent parameters and it can be stated that the groundwater from the Turkana County did not meet the Kenyan potable water standard requirements for electrical conductivity (EC) (7 samples), sodium (14 samples), calcium (1 sample), magnesium (1 sample), chloride (5 samples) and sulphate concentrations (2 samples). Nitrite concentrations did not fulfil the regulations for groundwater collected from 10 wells, as well as the nitrate concentrations, exceeded the WHO guideline value and KPWS maximum permissible levels in 2 cases. The presence of nitrogen species in the groundwater seems to be rather linked to anthropogenic and not to geogenic sources and can be caused by cattle breeding and insufficient latrine isolation. Especially relatively high concentration of $\mathrm{NO}_{3}{ }^{-}$found under oxidizing conditions may be a result of water recharge with anthropogenic contaminants.

\subsection{Speciation calculations}

The hydrogeochemical modelling based on thermodynamic calculations is a common method for evaluation of waterrock interactions and water treatment processes (Appelo 
Table 2 The correlation coefficient between $\mathrm{F}^{-}$and depth in aquifer formations

\begin{tabular}{lll}
\hline Formation & Fluoride $[\mathrm{mg} / \mathrm{L}]$ versus depth $[\mathrm{m}$ b.s.l.] \\
\cline { 2 - 3 } & Pearson correlation coefficient & Significant at $\alpha$ value \\
\hline All formations & -0.219 & 0.22 \\
Sedimentary rocks & $\mathbf{- 0 . 6 2 1 *}$ & $\mathbf{0 . 0 1 3}$ \\
Basement & 0.21 & 0.471 \\
Volcanic rocks & 0.625 & 0.375 \\
\hline
\end{tabular}

*Correlation is significant at the 0.05 level (2-tailed)

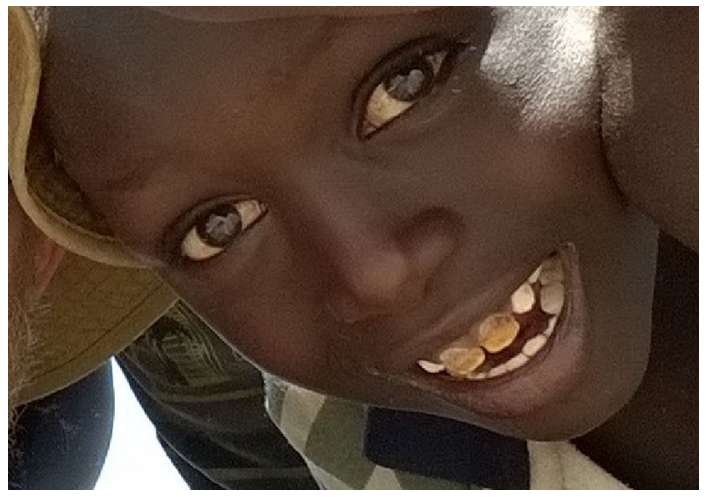

Fig. 3 Dental fluorosis in a child (photog. Piotr Stopa)

and Postma 2005; Tomaszewska et al. 2018) The results of chemical analyses were used for the calculation of speciation. Hydrogeochemical modelling was performed with PHREEQC 3.5 software (Parkhurst and Appelo 1999). Input data for initial solutions were $\mathrm{pH}$, temperature, redox conditions (pe/ion pares), $\mathrm{Na}^{+}, \mathrm{K}^{+}, \mathrm{Ca}^{2+}, \mathrm{Mg}^{2+}, \mathrm{HCO}_{3}{ }^{-}$, $\mathrm{SO}_{4}{ }^{2-}, \mathrm{Cl}^{-}, \mathrm{NO}_{2}^{-}, \mathrm{NO}_{3}^{-}, \mathrm{F}^{-}$. To evaluate the chemical equilibrium state between solid phases and aqueous solution the saturation indices were calculated for each mineral phase of interest (Parkhurst and Appelo 1999). Because chemical analyses and determination of temperature adjusted equilibrium constants $\mathrm{K}_{\mathrm{T}}$ are more or less biased with some error there is a widely adopted rule that the thermodynamic equilibrium between solution and concerned minerals phase is reached when the SI value is in the range of $\pm 5 \% \lg \mathrm{K}_{\mathrm{T}}$ (Dobrzyński 2006; Tomaszewska et al. 2017; Sekuła et al. 2020).

The redox conditions play an important role in the formation of the chemical composition of groundwater (Appelo and Postma 2005; Dobrzyński et al. 2018; Wątor et al. 2020). Thus, due to the lack of information about redox potential value $\left(E_{H}\right)$, the nitrogen species were used to determine the redox conditions by the calculation of electron activity (pe) using the $\mathrm{N}(\mathrm{V}) / \mathrm{N}(\mathrm{III})$ redox couple. The groundwater samples exhibit very similar redox conditions-pe values are in the range of 7.16-8.27. In the case of the lack of data for $\mathrm{NO}_{2}{ }^{-}$and $\mathrm{NO}_{3}{ }^{-}$concentrations, the pe value for the rest of the samples was calculated as a mean from the pe values computed for available redox species $\left(\mathrm{NO}_{3}{ }^{-} / \mathrm{NO}_{2}{ }^{-}\right)$due to the normal distribution of this parameter.

Saturation indices (SI) were calculated and plotted for selected minerals such as fluorite $\left(\mathrm{CaF}_{2}\right)$, anhydrite $\left(\mathrm{CaSO}_{4}\right)$, gypsum $\left(\mathrm{CaSO}_{4} \cdot 2 \mathrm{H}_{2} \mathrm{O}\right)$, and calcite $\left(\mathrm{CaCO}_{3}\right)$. Groundwater collected from all wells was undersaturated concerning anhydrite and gypsum despite a relatively high concentration of sulphate in several samples (Figs. 4, 5).

All samples showed very similar saturation indices for both phases. Groundwater undersaturated concerning sulphate minerals is capable to dissolve these phases assuming they are present in the rock matrix. Consequently, there can be precipitation of carbonates due to the common ion effect. It can be a reason for the relatively low concentration of $\mathrm{HCO}_{3}{ }^{-}$in samples with high $\mathrm{SO}_{4}{ }^{2-}$ (Karegi et al. 2018).

Undersaturation with respect to calcite (Fig. 6) is found in 11 samples with the simultaneous low concentration of calcium (mean concentration of calcium for these points is $11.54 \mathrm{mg} / \mathrm{L}$, medium $10.0 \mathrm{mg} / \mathrm{L}$, minimum 0.8 , and maximum $25.60 \mathrm{mg} / \mathrm{L}$ ). The concentration of bicarbonates was $361.7 \mathrm{mg} / \mathrm{L}$ with a minimum value of 97.6 and a maximum of $756.4 \mathrm{mg} / \mathrm{L}$. Under equilibrium state, there are 17 samples where the concentration of $\mathrm{Ca}$ was in the range from 3.2 to $656 \mathrm{mg} / \mathrm{L}$, mean value of $70.1 \mathrm{mg} / \mathrm{L}$, and median $18.0 \mathrm{mg} / \mathrm{L}$. Also, the mean bicarbonate concentration is $429.2 \mathrm{mg} / \mathrm{L}$, with a minimum of $148.8 \mathrm{mg} / \mathrm{L}$ and a maximum of $878.4 \mathrm{mg} / \mathrm{L}$. There are 7 samples supersaturated concerning calcite and they are characterised by significantly higher concentrations of bicarbonate (mean value of $2312 \mathrm{mg} / \mathrm{L}$, medium $851.6 \mathrm{mg} / \mathrm{L}$, minimum $463.6 \mathrm{mg} / \mathrm{L}$, and maximum value of $11468 \mathrm{mg} / \mathrm{L}$ ).

The principal mineral of interest is fluorite and 6 samples are at equilibrium with this phase. The mean concentration of fluoride ion for these samples is relatively high and equals $3.85 \mathrm{mg} / \mathrm{L}$, median $4.35 \mathrm{mg} / \mathrm{L}$. The minimum value of $1.85 \mathrm{mg} / \mathrm{L}$ exceeded the WHO and Kenyan maximum permissible level for drinking water. The maximum value is almost 4 times higher than the recommended 
Fig. 4 Saturation index for $\mathrm{CaSO}_{4}$ legend: blue pointundersaturated solution number and names of sampling points consistently to Table 1

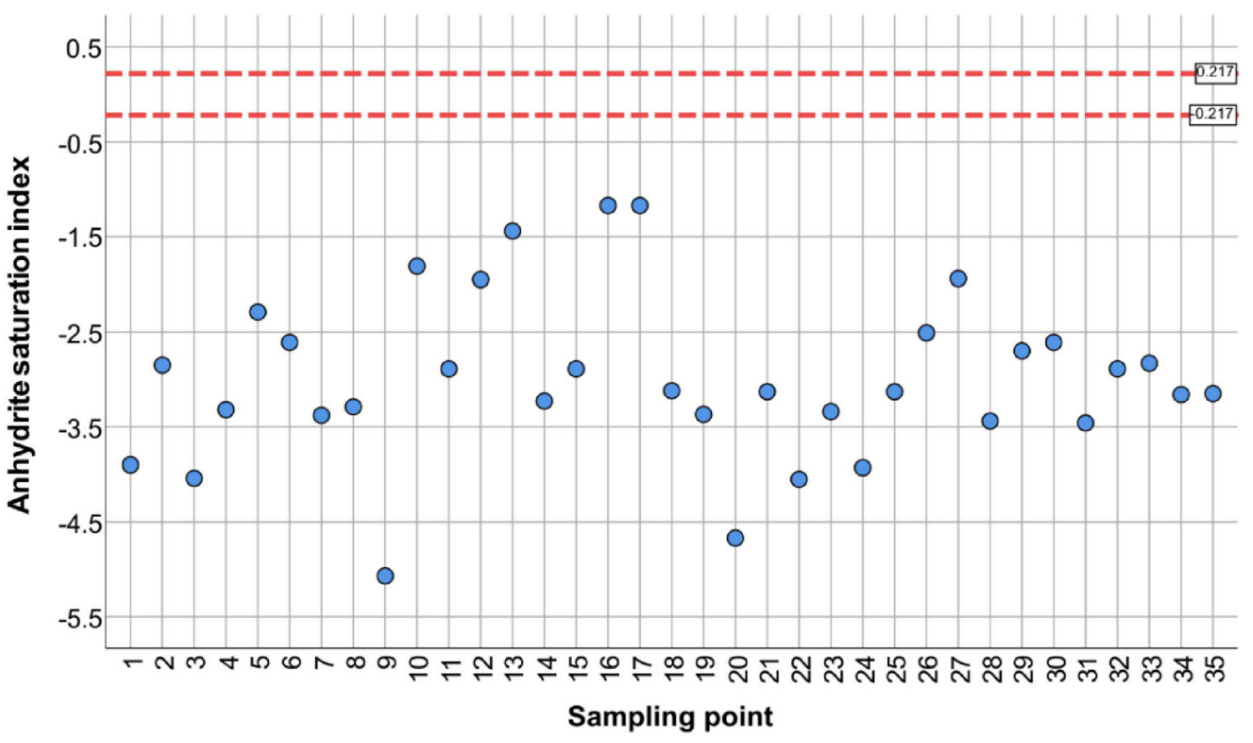

Fig. 5 Saturation index for $\mathrm{CaSO}_{4} \cdot 2 \mathrm{H}_{2} \mathrm{O}$ legend: blue pointu-ndersaturated solution

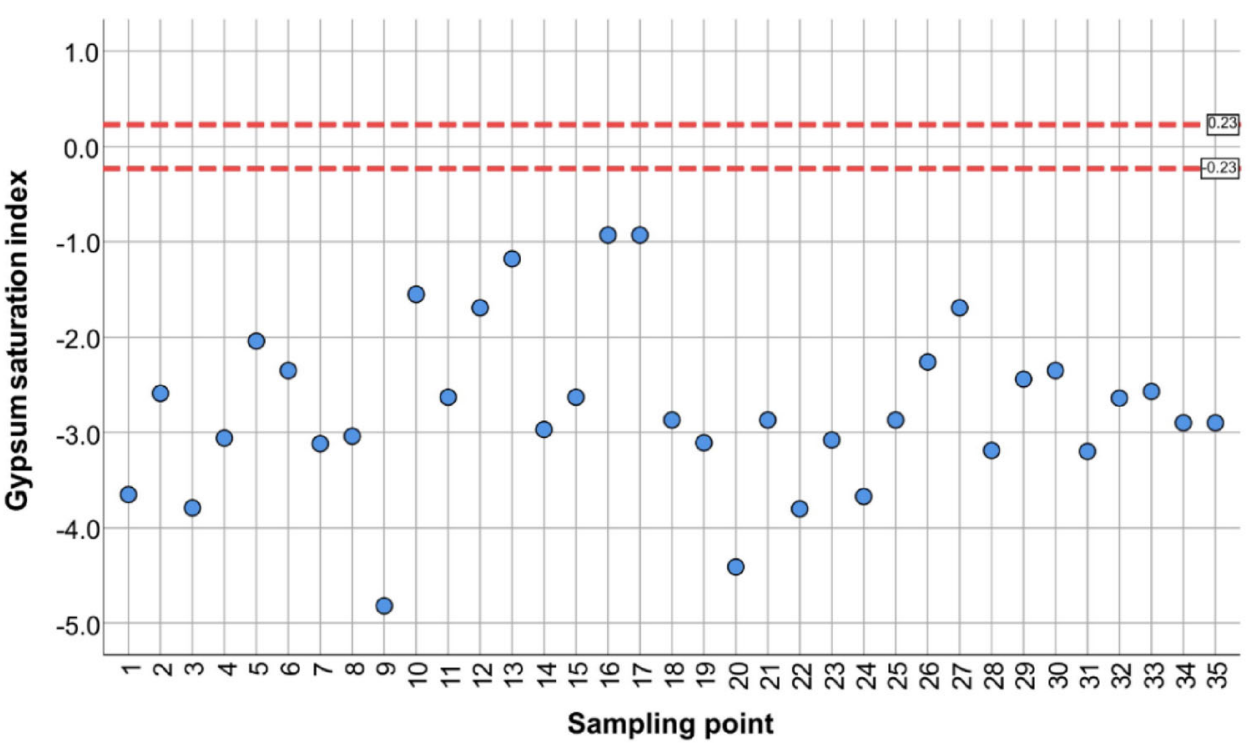

MPL, reaching $5.87 \mathrm{mg} / \mathrm{L}$. The rest of the samples is undersaturated, and they can be enriched in fluoride ions (Fig. 7).

\section{Discussion}

\subsection{Sources of high $\mathrm{Na}^{+}$in groundwater}

Most of the groundwater samples collected throughout Turkana County in Kenya are of the $\mathrm{Na}-\mathrm{HCO}_{3}$ hydrochemical type. Beyond $\mathrm{Na}^{+}$as a dominant cation and $\mathrm{HCO}_{3}{ }^{-}$as an anion, in several samples there are other prevailing ions $(>20 \% \mathrm{meq} / \mathrm{L})$ such as $\mathrm{Cl}^{-}$(16 samples), $\mathrm{Mg}^{2+}$ (10 samples), $\mathrm{Ca}^{2+}$ (4 samples), $\mathrm{SO}_{4}{ }^{2-}$ (2 samples), and $\mathrm{K}^{+}$(1 sample). In one sample (No. 27) there are no dominant cations. The $\mathrm{Na}-\mathrm{HCO}_{3}$ type of water is less common compared to $\mathrm{Ca}-\mathrm{HCO}_{3}$ or $\mathrm{Ca}-\mathrm{Mg}-\mathrm{HCO}_{3}$ types characteristic for freshwaters and resulting from the dissolution of the carbonate minerals such as calcite, aragonite, and dolomite. The process controlling the relatively high concentration of sodium in groundwater is chemical weathering of Na-feldspar (1) with the simultaneous release of sodium ions and bicarbonates (Toran and Saunders 1999; Dupalová et al. 2012; Kumar et al. 2017):

$$
\begin{aligned}
\mathrm{NaAlSi}_{3} \mathrm{O}_{8}+\mathrm{H}_{2} \mathrm{CO}_{3}+\mathrm{H}_{2} \mathrm{O}= & \mathrm{Na}^{+}+\mathrm{HCO}_{3}^{-}+\mathrm{H}_{4} \mathrm{SiO}_{4} \\
& +\mathrm{Al}_{2} \mathrm{Si}_{2} \mathrm{O}_{5}(\mathrm{OH})_{4}
\end{aligned}
$$

The production of $\mathrm{Na}^{+}$and $\mathrm{HCO}_{3}{ }^{-}$in groundwater may also be caused by cation exchange of $\mathrm{Na}^{+}$on exchange 
Fig. 6 Saturation index for $\mathrm{CaCO}_{3}$ legend: red pointsupersaturated solution, greenthermodynamic equilibrium, blue-undersaturated solution

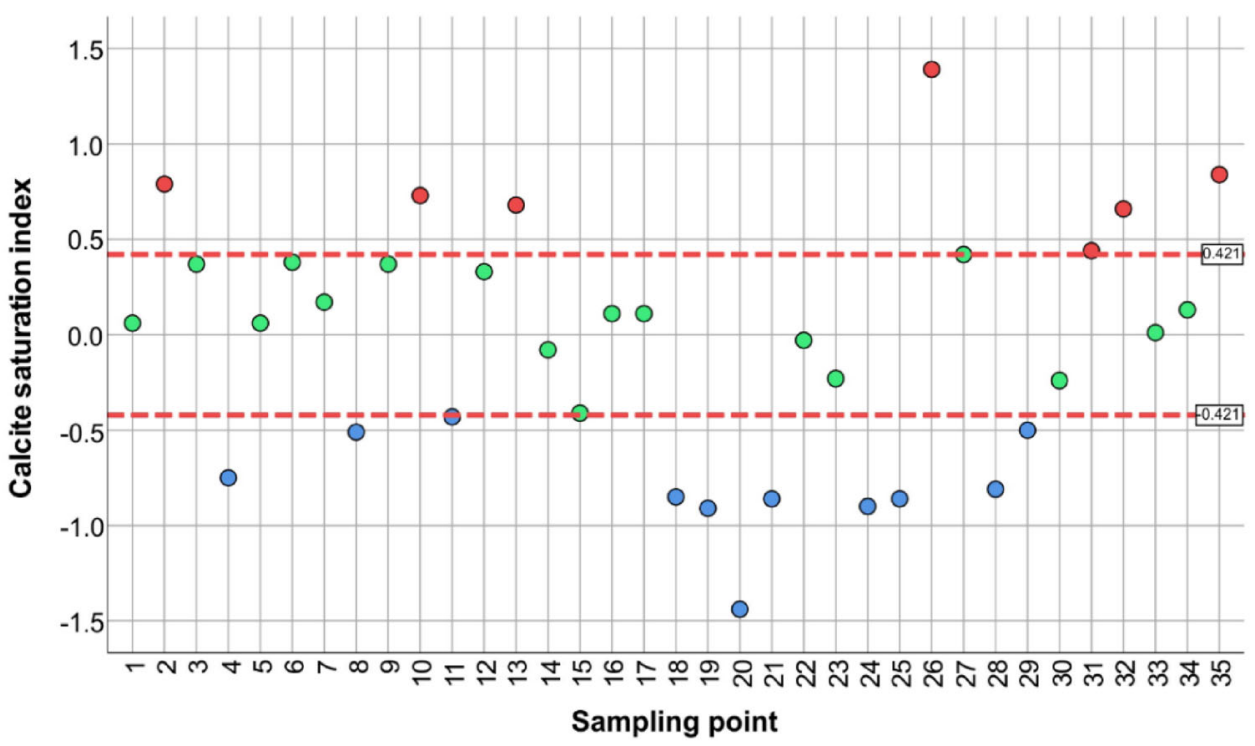

sites by $\mathrm{Ca}^{2+}$ coupled with dissolution of carbonates (Sracek and Hirata 2002; Sracek et al. 2019):

$$
\begin{gathered}
\mathrm{CaCO}_{3}+\mathrm{CO}_{2}+\mathrm{H}_{2} \mathrm{O}+\mathrm{Na}_{2}-\mathrm{X} \\
\quad=2 \mathrm{Na}^{+}+2 \mathrm{HCO}_{3}^{-}+\mathrm{Ca}-\mathrm{X}
\end{gathered}
$$

where $\mathrm{X}$ denotes exchange sites. Both processes produce $\mathrm{Na}-\mathrm{HCO}_{3}$ type of groundwater with high $\mathrm{pH}$ values and mineralization.

\subsection{Fluoride ions sources in groundwater}

In groundwater, the occurrence of fluoride is often linked to the volcanic rocks and its concentration is controlled by alkalinity, the concentration of bicarbonates, and electrical conductivity (Ali et al. 2016, 2018; Alarcón-Herera 2013; Alarcón-Herrera et al. 2020; Saxena and Ahmed 2001). Groundwater enrichment in fluoride ions may have an origin in chemical weathering, magmatic processes, atmospheric dust, and industrial pollution. Precipitation of mineral-like $\mathrm{CaCO}_{3}$ in solution with the slightly alkaline or alkaline $\mathrm{pH}$ value will favour decreasing of $\mathrm{Ca}$ ions concentration with simultaneous enrichment in $\mathrm{F}^{-}$ions through the dissolution of fluorite until the thermodynamic equilibrium with this phase is reached (Gizaw 1996; Kumar and Singh 2015; Rafique et al. 2015). Groundwater around the world containing a high concentration of fluoride exhibits often the $\mathrm{Na}-\mathrm{HCO}_{3}$ type with a low concentration of calcium and/or magnesium ions (AlarcónHerrera 2013; Sracek et al. 2015). Also, fluoride is present in groundwater as anion $\mathrm{F}^{-}$and is desorbed at high $\mathrm{pH}$ values above $\mathrm{pH}_{\mathrm{ZPC}}$ just like other anionic species of As, Mo, Se, and V (Appelo and Postma 2005). The link of high $\mathrm{F}^{-}$to $\mathrm{Na}-\mathrm{HCO}_{3}$ type of groundwater has been observed, e.g., at the Chaco-Pampean Plain in Argentina (Smedley et al. 2002; Bhattacharya et al. 2006), the Main Ethiopian Rift (Bretzler et al. 2011), and southeast and central Sri Lanka (Edmunds and Smedley 2004) with similar climatic and hydrogeological conditions as in the Turkana Lake region.

\subsection{Correlation between $\mathrm{F}^{-}$and $\mathrm{Ca}^{2+}$ ions}

In research studies presented, e.g., by Gizaw (1996), Rafique et al. (2015), and Kumar et al. (2017) there was found an inverse relationship between the concentration of $\mathrm{F}^{-}$and $\mathrm{Ca}^{2+}$ in investigated natural waters. It is related to the solubility control by precipitation fluorite when supersaturation concerning the mineral phase is reached. In the saturation indices plot, only 6 samples stay in thermodynamic equilibrium with $\mathrm{CaF}_{2}$ (Fig. 8). For these points, there was a check of the equilibrium state with $\mathrm{CaCO}_{3}$. Two points, i.e., Kalemngorok (No. 10), and Nataparkakonok (No. 31) show supersaturation with this mineral phase manifesting a tendency for precipitation of calcite. Kapendo (No. 12) and Nakwamekwi parish $\mathrm{BH}$ (No. 27) samples are in the upper range of SI values and the Keenyenyuk sample (No. 15) is in the middle of the interval for thermodynamic equilibrium. When these points are plotted, there is a significant Pearson correlation coefficient $(p<0.05)$ for the inverse correlation between calcium ions and fluoride ions with the value of $\mathrm{R}=-0.993$ (Fig. 7a) as expected based on $\mathrm{CaF}_{2}$ solubility control of dissolved $\mathrm{F}^{-}$(Appelo and Postma 2005). However, when all points are included in the plot, there is no correlation (Fig. 7b), suggesting these processes operate only locally. 

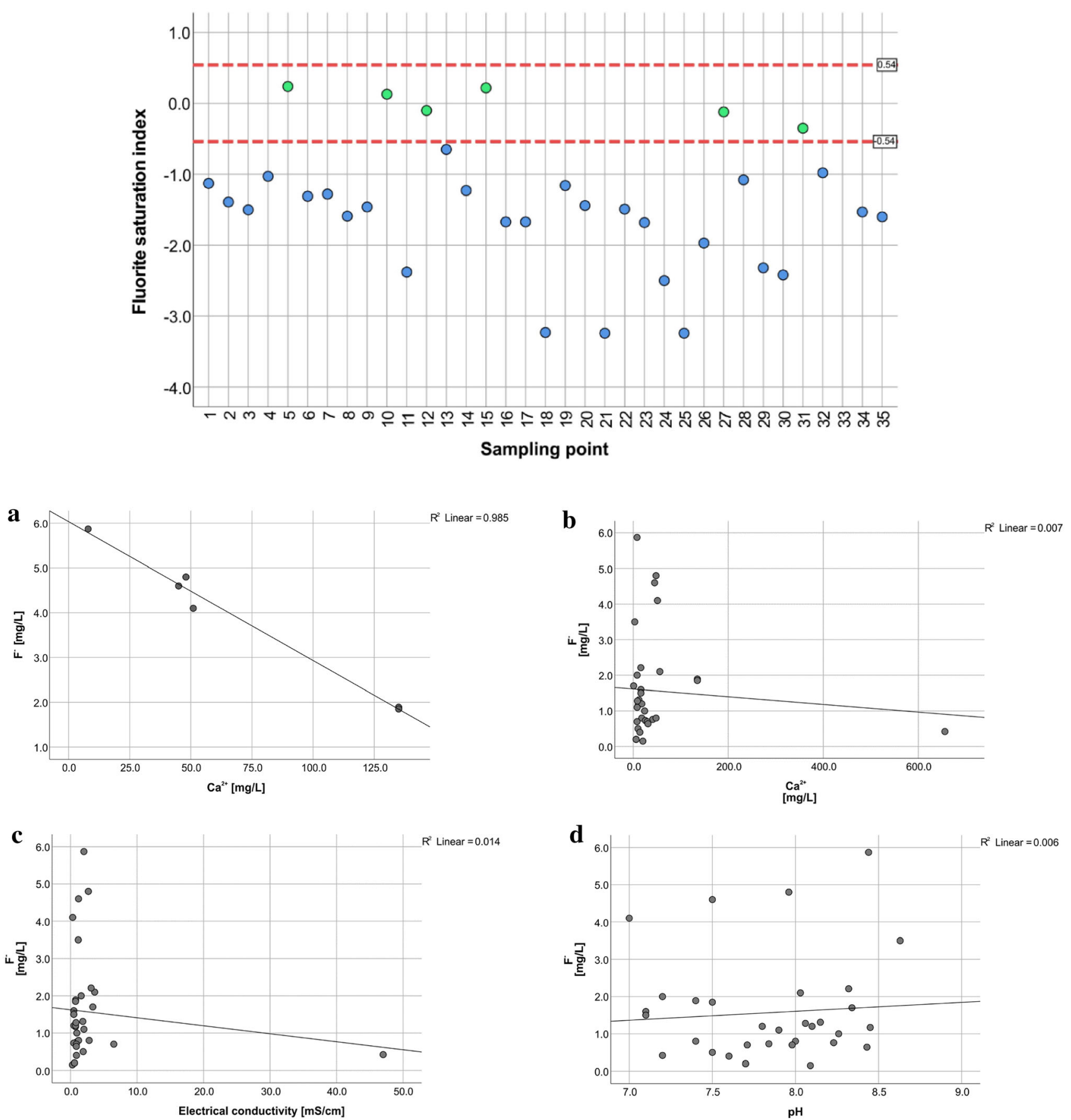

Fig. 7 Saturation index for $\mathrm{CaF}_{2}$ legend: greent—hermodynamic equilibrium, blue—undersaturated solution

\subsection{Correlation between $\mathrm{F}^{-}$and $\mathrm{EC}, \mathrm{pH}$}

There is no correlation between $\mathrm{F}^{-}$and EC representing mineralization (Fig. 7c), suggesting that evaporation is not the principal process responsible for high $\mathrm{F}^{-}$ concentrations.
Similarly, the lack of correlation between $\mathrm{pH}$ and $\mathrm{F}^{-}$ (Fig. 7d), suggesting that desorption of F- under increasing $\mathrm{pH}$ conditions is not significant. However, the possibility of competition with trace elements forming anionic species for adsorption sites should be checked in future studies. 

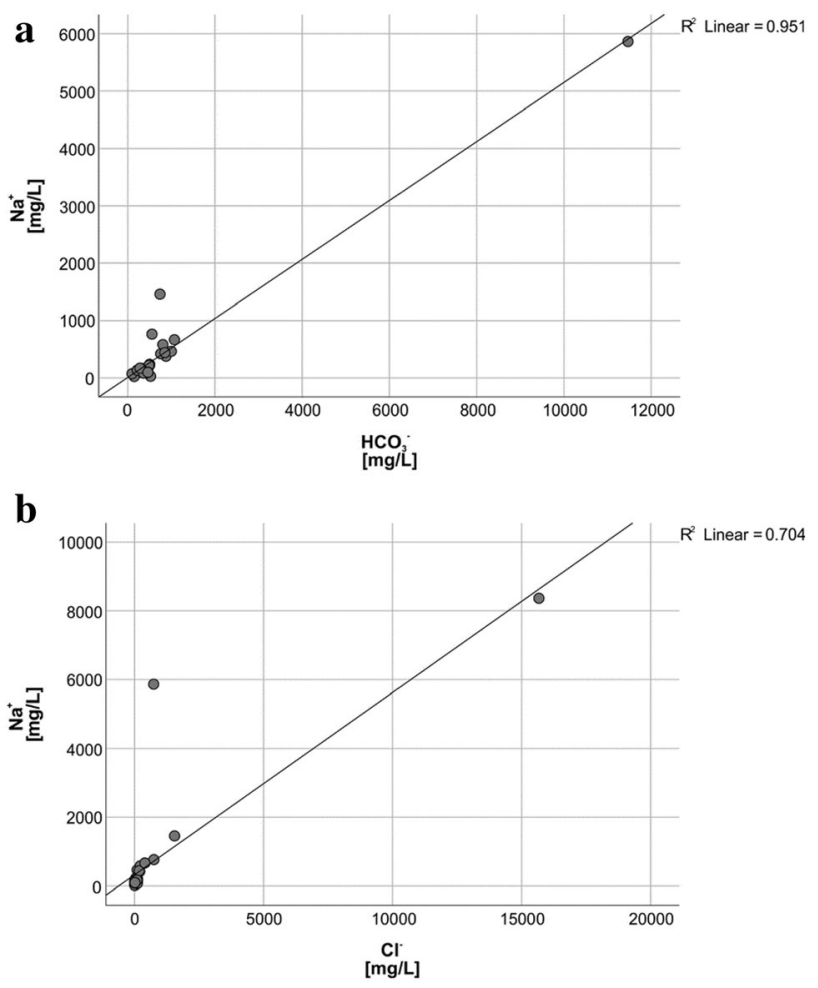

Fig. 8 a $\mathrm{Na}$ vs $\mathrm{HCO}_{3}$ for all data $\mathbf{b} \mathrm{Na}$ vs $\mathrm{Cl}$ for all data

\subsection{Relationship between $\mathrm{Na}^{+}$and $\mathrm{F}^{-}$ions}

Also, $\mathrm{Na}^{+}$ions have a strong positive correlation with $\mathrm{HCO}_{3}{ }^{-}$probably as a consequence of the sodium feldspar weathering in the aquifers and/or cation exchange coupled to the dissolution of carbonates (Fig. 8a). This correlation has been observed in F-rich groundwaters in Ethiopia (Bretzler et al. 2011) and Namibia (Sracek et al. 2015). For samples, where the sampled wells are installed in sandy riverbed sediments, a high concentration of sodium may be a result of hydraulic contact of groundwater with local surface water bodies. The water in the Kenyan rivers and lakes exhibit slightly alkaline to alkaline $\mathrm{pH}$ with increasing concentration of $\mathrm{Na}+, \mathrm{HCO}_{3}{ }^{-}$, and $\mathrm{Cl}^{-}$ions as a result of strong evaporation (Gizaw 1996; Cerling 1979; Yuretich and Cerling 1983). Concentrations of $\mathrm{Na}^{+}$ and $\mathrm{Cl}^{-}$increase in parallel (Fig. $8 \mathrm{~b}$ ) because both ions behave conservatively, i.e., they remain dissolved, until advanced evaporation stages with resulting formation of a brine (Drever 1997).

In our study concentration of sodium perhaps is mostly restricted to the water horizon which constitutes of sands and gravels with locally alternated with clay formation, weathered and/or fractured gneisses (granitoid, pegmatic, biotite, epidotised), and mafic rocks like basalts with different degree of weathering and linked to the Tertiary volcanic rocks.

On a regional scale, $\mathrm{F}^{-}$ions revealed only a slightly positive correlation $(\mathrm{R}=0.350)$ with $\mathrm{K}^{+}$ions. It suggests that a potential source of $\mathrm{F}^{-}$and $\mathrm{K}^{+}$in groundwater can be the dissolution of biotite (Chae et al. 2006), being one of the principal minerals in gneiss or weathered/fractured granitoid gneiss.

\section{Conclusions}

Investigations of the groundwater collected from the wells in the Turkana County in Kenya revealed relatively high concentrations of fluoride ions in the range from 0.15 to $5.87 \mathrm{mg} / \mathrm{L}$. Almost half of the samples have a higher value of $\mathrm{F}^{-}$than the WHO guideline value and the Kenyan potable water standard of $1.5 \mathrm{mg} / \mathrm{L}$. Drinking water with an elevated concentration of fluoride can lead to healthrelated issues like dental or skeletal fluorosis or even to hypocalcaemia while precipitating $\mathrm{CaF}_{2}$ in the human organism. Some prevention programs and water treatment should be applied to prevent negative (even serious) health problems that may result from the consumption of contaminated groundwater. Hydrogeochemical facies has shown that the groundwater in the majority is of $\mathrm{Na}-\mathrm{HCO}_{3}$ type which is significantly linked to high $\mathrm{F}^{-}$concentrations, just like observed elsewhere, e.g., in Argentina, Ethiopia, and Namibia. These results suggest geogenic sources of $\mathrm{F}^{-}$. Process of controlling the high concentration of $\mathrm{F}^{-}$ions in groundwater seems to be precipitation of $\mathrm{CaCO}_{3}$ decreasing $\mathrm{Ca}^{2+}$ concentration followed by the dissolution of $\mathrm{CaF}_{2}$ and enrichment of groundwater in $\mathrm{F}^{-}$. Simultaneously, chemical weathering of sodium feldspar in the aquifer matrix and cation exchange of $\mathrm{Ca}^{2+}$ for $\mathrm{Na}^{+}$on the exchange sites result in the formation of alkaline $\mathrm{pH}$, $\mathrm{Na}-\mathrm{HCO}_{3}$ type of groundwater with a high concentration of $\mathrm{F}^{-}$. Further studies should be focused on other trace elements forming anionic species like As and V.

Acknowledgements The authors are very thankful to the Government Chemist's Department of the Republic of Kenya and local institutions for sharing the data used in this paper.

Authors' contributions Conceptualization, P.R, K.S.; methodology, P.R.; formal analysis, P.R., O.S., K.S.; investigation, P.S., K.S., P.R.; writing - original draft preparation, P.R..; writing-review and editing, P.R., O.S., and K.S.; supervision, O.S. and K.S. All authors have read and agreed to the published version of the manuscript.

Funding The study was partially financed by AGH-UST 16.16.140.315/10. 


\section{Declarations}

Conflict of interest The authors declare that they have no known competing financial interests or personal relationships that could have appeared to influence the work reported in this paper.

Open Access This article is licensed under a Creative Commons Attribution 4.0 International License, which permits use, sharing, adaptation, distribution and reproduction in any medium or format, as long as you give appropriate credit to the original author(s) and the source, provide a link to the Creative Commons licence, and indicate if changes were made. The images or other third party material in this article are included in the article's Creative Commons licence, unless indicated otherwise in a credit line to the material. If material is not included in the article's Creative Commons licence and your intended use is not permitted by statutory regulation or exceeds the permitted use, you will need to obtain permission directly from the copyright holder. To view a copy of this licence, visit http://creativecommons. org/licenses/by/4.0/.

\section{References}

Abdurahman SG, Zewdie M (2018) Fluoride ion and total dissolved solid distribution in Ethiopian Rift valley: the case of Hawassa city aquifer. J Hydrol Reg Stud 19:240-249. https://doi.org/10. 1016/j.ejrh.2018.09.003

Abiye T, Bybee G, Leshomo J (2018) Fluoride concentrations in the arid Namaqualand and the Waterberg groundwater South Africa: understanding the controls of mobilization through hydrogeochemical and environmental isotopic approaches. Ground Sustain Dev 6:112-120. https://doi.org/10.1016/j.gsd.2017.12.004

Alarcón-Herrera MT, Bundschuh J, Nath B, Nicolli HB, Gutierrez M, Reyes-Gomez VM, Nuñez D, Martín-Dominguez IR, Sracek O (2013) Co-occurrence of arsenic and fluoride in groundwater of semi-arid regions in Latin America: genesis, mobility and remediation. J Hazard Mater 262:960-969. https://doi.org/10. 1016/j.jhazmat.2012.08.005

Alarcón-Herrera MT, Martin-Alarcón DA, Gutiérrez M, ReynosoCuevas L, Martín-Domínguez A, Olmos-Márquez MA, Bundschuh J (2020) Co-occurrence possible origin and health-risk assessment of arsenic and fluoride in drinking water sources in Mexico: geographical data visualization. Sci Total Environ 698:134168. https://doi.org/10.1016/j.scitotenv.2019.134168

Ali S, Thakur SK, Sarkar A, Shekhar S (2016) Worldwide contamination of water by fluoride. Environ Chem Lett 14(3):291-315. https://doi.org/10.1007/s10311-016-0563-5

Ali S, Shekhar S, Bhattacharya P, Verma G, Chandrasekhar T, Chandrashekhar AK (2018) Elevated fluoride in groundwater of Siwani Block Western Haryana India: a potential concern for sustainable water supplies for drinking and irrigation. Ground Sustain Dev 7:410-420. https://doi.org/10.1016/j.gsd.2018.05. 008

Ali S, Fakhri Y, Golbini M, Thakur SK, Alinejad A, Parseh I, Shekhar S, Bhattacharya P (2019a) Concentration of fluoride in groundwater of India: a systematic review meta-analysis and risk assessment. Ground Sustain Dev. https://doi.org/10.1016/j.gsd. 2019.100224

Ali W, Aslam MW, Junaid M, Ali K, Guo Y, Rasool A, Zhang H (2019b) Elucidating various geochemical mechanisms drive fluoride contamination in unconfined aquifers along the major rivers in Sindh and Punjab Pakistan. Environ Pollut 249:535-549. https://doi.org/10.1016/j.envpol.2019.03.043

Apambire WB, Boyle DR, Michel FA (1997) Geochemistry, genesis, and health implications of fluoriferous groundwater in the upper regions of Ghana. Environ Geol 33(1):13-24. https://doi.org/10. 1007/s002540050221

Appelo CAJ, Postma D (2005) Geochemistry groundwater and pollution, 2nd edn. Balkema, Rotterdam

Berger T, Mathurin FA, Drake H, Åström ME (2016a) Fluoride abundance and controls in fresh groundwater in Quaternary deposits and bedrock fractures in an area with fluorine-rich granitoid rocks. Sci Total Environ 569:948-960. https://doi.org/ 10.1016/j.scitotenv.2016.06.002

Berger T, Yu C, Drake H, Peltola P, Svensson D, Åström ME (2016b) Fluorine geochemistry of quaternary deposits in a nemo-boreal catchment with elevated dissolved fluoride in surface waters and groundwater. J Geochem Explor 170:148-156. https://doi.org/ 10.1016/j.gexplo.2016.09.003

Bhattacharya P, Claesson M, Bundschuh J, Sracek O, Fagerberg J, Jacks G, Martin RA, del Storniolo A, Thir JM (2006) Distribution and mobility of arsenic in the Rio Dulce alluvial aquifers in Santiago del Estero Province, Argentina. Sci Total Environ 358(1-3):97-120. https://doi.org/10.1016/j.scitotenv.2005.04. 048

Bretzler A, Osenbrück K, Gloaguen R, Ruprecht JS, Kebede S, Stadler S (2011) Groundwater origin and flow dynamics in active rift systems - A multi-isotope approach in the Main Ethiopian Rift. J Hydrol 402(3-4):274-289. https://doi.org/10.1016/j.jhy drol.2011.03.022

Cerling TE (1979) Paleochemistry of plio-pleistocene lake Turkana, Kenya. Palaeogeogr Palaeoclimatol Palaeoecol 27:247-285. https://doi.org/10.1016/0031-0182(79)90105-6

Chae GT, Yun ST, Kwon MJ, Kim YS, Mayer B (2006) Batch dissolution of granite and biotite in water: implication for fluorine geochemistry in groundwater. Geochem J 40(1):95-102. https://doi.org/10.2343/geochemj.40.95

Chae GT, Yun ST, Mayer B, Kim KH, Kim SY, Kwon JS, Kim K, Koh YK (2007) Fluorine geochemistry in bedrock groundwater of South Korea. Sci Total Environ 385(1-3):272-283. https:// doi.org/10.1016/j.scitotenv.2007.06.038

Chief Geologist Mines and Geological Department (1962) National Atlas of Kenya, Geological Map, Survey of Kenya, Nairobi.

Colombani N, Di Giuseppe D, Kebede S, Mastrocicco M (2018) Assessment of the anthropogenic fluoride export in Addis Ababa urban environment (Ethiopia). J Geochem Explor 190:390-399. https://doi.org/10.1016/j.gexplo.2018.04.008

Craig L, Thomas JM, Lutz A, Decker DL (2018) Determining the optimum locations for pumping low-fluoride groundwater to distribute to communities in a fluoridic area in the Upper East Region Ghana. Chem Geol 476:481-492. https://doi.org/10. 1016/j.chemgeo.2017.12.001

Dehbandi R, Moore F, Keshavarzi B (2017) Provenance and geochemical behavior of fluorine in the soils of an endemic fluorosis belt central Iran. J Afr Earth Sci 129:56-71. https://doi. org/10.1016/j.jafrearsci.2016.12.016

Dehbandi R, Moore F, Keshavarzi B (2018) Geochemical sources, hydrogeochemical behavior, and health risk assessment of fluoride in an endemic fluorosis area, central Iran. Chemosphere 19:763-776. https://doi.org/10.1016/j.chemosphere.2017.11.021

Deng L, Zhang X, Zhang M, Jia X (2018) Effect of $\mathrm{CaF}_{2}$ on viscosity structure and properties of $\mathrm{CaO}-\mathrm{Al}_{2} \mathrm{O}_{3}-\mathrm{MgO}-\mathrm{SiO}_{2}$ slag glass ceramics. J Non-Cryst Solids 500:310-316. https://doi.org/10. 1016/j.jnoncrysol.2018.08.018

Dobrzyński D (2006) Chemistry of groundwater. In: Macioszczyk A (ed) Basics of applied hydrogeology. PWN, Warszawa

Dobrzyński D, Kmiecik E, Wator K (2018) Oxidation reduction potential-an informative and unused indicator of curative and mineral water quality. Acta Balneol 60(4):233-238 
Dodson RG (1971) Geology of the Area South of Lodwar: Degree Sheet 18 NE Quarter with Coloured Geological Map (No 87). Republic of Kenya, Ministry of Natural Resources

Drever JI (1997) The geochemistry of natural waters surface and groundwater environments, 3rd edn. Prentice Hall, Hoboken

Dupalová T, Sracek O, Vencelides Z, Žák K (2012) The origin of thermal waters in the northeastern part of the Eger Rift, Czech Republic. Appl Geochem 27(3):689-702. https://doi.org/10. 1016/j.apgeochem.2011.11.016

Edmunds WM, Smedley PL (2004) Fluoride in natural waters. In: Selinus O (ed) Essentials of medical geology. Elsevier, Amsterdam

Emenike CP, Tenebe IT, Jarvis P (2018) Fluoride contamination in groundwater sources in Southwestern Nigeria: assessment using multivariate statistical approach and human health risk. Ecotox Environ Safe 156:391-402. https://doi.org/10.1016/j.ecoenv. 2018.03.022

Enalou HB, Moore F, Keshavarzi B, Zarei M (2018) Source apportionment and health risk assessment of fluoride in water resources, south of Fars province, Iran: stable isotopes $(\delta 180$ and $\delta \mathrm{D})$ and geochemical modeling approaches. Appl Geochem 98:197-205. https://doi.org/10.1016/j.apgeochem.2018.09.019

Ferrer N, Folch A, Lane M, Olago D, Odida J, Custodio E (2019) Groundwater hydrodynamics of an Eastern Africa coastal aquifer, including La Niña 2016-17 drought. Sci Total Environ 661:575-597. https://doi.org/10.1016/j.envpol.2019.113646

Fordyce FM (2011) Fluorine: human health risks. In: Nriagu JO (ed) Encyclopedia of environmental health, vol 2. Elsevier, Amsterdam

Fuge R (2019) Fluorine in the environment, a review of its sources and geochemistry. Appl Geochem 100:393-406. https://doi.org/ 10.1016/j.apgeochem.2018.12.016

Gaciri SJ, Davies TC (1993) The occurrence and geochemistry of fluoride in some natural waters of Kenya. J Hydrol 143(3-4):395-412. https://doi.org/10.1016/00221694(93)90201-J

Gizaw B (1996) The origin of high bicarbonate and fluoride concentrations in waters of the Main Ethiopian Rift Valley, East African Rift system. J Afr Earth Sci 22(4):391-402. https:// doi.org/10.1016/0899-5362(96)00029-2

Guo H, Zhang Y, Xing L, Jia Y (2012) Spatial variation in arsenic and fluoride concentrations of shallow groundwater from the town of Shahai in the Hetao basin, Inner Mongolia. Appl Geochem 27(11):2187-2196. https://doi.org/10.1016/j.apgeochem.2012. 01.016

Gupta R, Misra AK (2018) Groundwater quality analysis of quaternary aquifers in Jhajjar District Haryana India: focus on groundwater fluoride and health implications. Alex Eng J 57(1):375-381. https://doi.org/10.1016/j.aej.2016.08.031

Handford CR (1987) Turkana Grits-a Cretaceous braided alluvial system in northern Kenya. AAPG (Am Assoc Pet Geol) Bull; (United States) 71(CONF-870606-)

Hong X, Liang H, Chen Y, Liu Y, Shi Y (2018) Distribution of fluorine in the surface dust of Wuda coal base, Inner Mongolia of Northern China. J Geochem Explor 188:390-397. https://doi.org/ 10.1016/j.gexplo.2018.02.012

Hsu CL, Lin WS, Lin CH, Liu J (2018) The effect of professional fluoride application program for preschool children in Taiwan: an analysis using the National Health Insurance Research Database (NHIRD). J Dent Sci 13(3):248-255. https://doi.org/ 10.1016/j.jds.2018.04.001

Hu S, Luo T, Jing C (2013) Principal component analysis of fluoride geochemistry of groundwater in Shanxi and Inner Mongolia China. J Geochem Explor 135:124-129. https://doi.org/10.1016/ j.gexplo.2012.08.013
Kanagaraj G, Elango L (2019) Chromium and fluoride contamination in groundwater around leather tanning industries in southern India: implications from stable isotopic ratio $\delta 53 \mathrm{Cr} / \delta 52 \mathrm{Cr}$, geochemical and geostatistical modelling. Chemosphere 220:943-953. https://doi.org/10.1016/j.chemosphere.2018.12. 105

Karegi S, Macharia K, Muthengia W, Mwiti MJ (2018) Hydrogeochemistry of ground water in mbeere south sub-county, Kenya. Int J Chem 10(4):173-183. https://doi.org/10.5539/ijc. v10n4p173

Khairnar MR, Dodamani AS, Jadhav HC, Naik RG, Deshmukh MA (2015) Mitigation of fluorosis-a review. JCDR 9(6):ZE05-ZE09

Kravchenko J, Rango T, Akushevich I, Atlaw B, McCornick PG, Merola RB, Paul C, Weinthal E, Harrison C, Vengosh A, Jeuland M (2014) The effect of non-fluoride factors on risk of dental fluorosis: evidence from rural populations of the Main Ethiopian Rift. Sci Total Environ 488:595-606. https://doi.org/10.1016/j. scitotenv.2013.12.087

Kumar A, Singh CK (2015) Characterization of hydrogeochemical processes and fluoride enrichment in groundwater of southwestern Punjab. Water Qual Expo Health 7(3):373-387

Kumar P, Singh CK, Saraswat C, Mishra B, Sharma T (2017) Evaluation of aqueous geochemistry of fluoride enriched groundwater: a case study of the Patan district, Gujarat, Western India. Water Sci 31(2):215-229. https://doi.org/10.1016/j.wsj. 2017.05.002

Kumar S, Venkatesh AS, Singh R, Udayabhanu G, Saha D (2018) Geochemical signatures and isotopic systematics constraining dynamics of fluoride contamination in groundwater across Jamui district, Indo-Gangetic alluvial plains, India. Chemosphere 205:493-505. https://doi.org/10.1016/j.chemosphere.2018.04. 116

KWPS (2014) Kenya Standard potable water specification KS EAS 12: 2014 ICS 1306020 First Edition.

Laxmankumar D, Satyanarayana E, Dhakate R, Saxena PR (2019) Hydrogeochemical characteristics with respect to fluoride contamination in groundwater of Maheshwarm mandal, RR district, Telangana state, India. Ground Sustain Dev 8:474-483. https:// doi.org/10.1016/j.gsd.2019.01.008

Martins VTDS, Pino DS, Bertolo R, Hirata R, Babinski M, Pacheco DF, Rios AP (2018) Who to blame for groundwater fluoride anomaly in São Paulo Brazil? Hydrogeochemistry and isotopic evidence. Appl Geochem 90:25-38. https://doi.org/10.1016/j. apgeochem.2017.12.020

Mika A, Wạtor K, Kmiecik E (2018) Determination of fluorides in mineral and curative water-method validation. Acta Balneol 60(4):258-263

Milojkov DV, Silvestre OF, Stanić VD, Janjić GV, Mutavdžić DR, Milanović M, Nieder JB (2020) Fabrication and characterization of luminescent Pr3+ doped fluorapatite nanocrystals as bioimaging contrast agents. J Lumin 217:116757. https://doi.org/10. 1016/j.jlumin.2019.116757

Mondal D, Gupta S, Reddy DV, Nagabhushanam P (2014) Geochemical controls on fluoride concentrations in groundwater from alluvial aquifers of the Birbhum district, West Bengal, India. J Geochem Explor 145:190-206. https://doi.org/10.1016/j. gexplo.2014.06.005

Msonda KWM, Masamba WRL, Fabiano E (2007) A study of fluoride groundwater occurrence in Nathenje, Lilongwe, Malawi. Phys Chem Earth Pt A/b/c 32(15-18):1178-1184. https://doi.org/10. 1016/j.pce.2007.07.050

Naderi M, Jahanshahi R, Dehbandi R (2020) Two distinct mechanisms of fluoride enrichment and associated health risk in springs' water near an inactive volcano, southeast Iran. Ecotox Environ Safe 195:110503. https://doi.org/10.1016/j.ecoenv.2020. 110503 
Nair KR, Manji F, Gitonga JN (1984) The occurrence and distribution of fluoride in groundwaters of Kenya. East Afr Med J 61(7):503-512

Ochungo EA, Ouma GO, Obiero JPO, Odero NA (2020) Impact of Drought on Ground Water Quality in Langata Sub-County, Kenya. Am J Water Resour 8(3):145-154. https://doi.org/10. 12691/ajwr-8-3-5

Oduor A, Cherogony K, Mutune J, Malesu M, Karuma A, Cherogony M, Nyolei D, Kandagor J, Onyango D (2012) Food security master plan for Turkana County. Diocese of Lodwar.

Olaka LA, Wilke FD, Olago DO, Odada EO, Mulch A, Musolff A (2016) Groundwater fluoride enrichment in an active rift setting: central Kenya Rift case study. Sci Total Environ 545:641-653. https://doi.org/10.1016/j.scitotenv.2015.11.161

Ozsvath DL (2006) Fluoride concentrations in a crystalline bedrock aquifer Marathon County, Wisconsin. Environ Geol 50:132-138. https://doi.org/10.1007/s00254-006-0192-6

Parkhurst DL, Appelo CAJ (1999) User's guide to PHREEQC-a computer program for speciation reaction-path 1D-transport and inverse geochemical calculations. US Geol Survey WaterResour Investig Rep 99:4259

Pauwels H, Négrel P, Dewandel B, Perrin J, Mascré C, Roy S, Ahmed S (2015) Hydrochemical borehole logs characterizing fluoride contamination in a crystalline aquifer (Maheshwaram India). J Hydrol 525:302-312. https://doi.org/10.1016/j.jhydrol.2015.03. 017

Pettifor JM, Schnitzler CM, Ross FP, Moodley GP (1989) Endemic skeletal fluorosis in children: hypocalcemia and the presence of renal resistance to parathyroid hormone. Bone Miner 7(3):275-288. https://doi.org/10.1016/0169-6009(89)90084-6

Podder S, Akbari S, Roy S (2012) Cryolite induced morphological change in the compound eye of Drosophila melanogaster. Fluoride 45(1):58-64

Rafique T, Naseem S, Ozsvath D, Hussain R, Bhanger MI, Usmani TH (2015) Geochemical controls of high fluoride groundwater in Umarkot sub-district, Thar Desert, Pakistan. Sci Total Environ 530:271-278. https://doi.org/10.1016/j.scitotenv.2015.05.038

Raj D, Shaji E (2017) Fluoride contamination in groundwater resources of Alleppey, southern India. Geosci Front 8(1):117-124. https://doi.org/10.1016/j.gsf.2016.01.002

Raju NJ (2017) Prevalence of fluorosis in the fluoride enriched groundwater in semi-arid parts of eastern India: geochemistry and health implications. Quat Int 443:265-278. https://doi.org/ 10.1016/j.quaint.2016.05.028

Rango T, Bianchini G, Beccaluva L, Tassinari R (2010) Geochemistry and water quality assessment of central Main Ethiopian Rift natural waters with emphasis on source and occurrence of fluoride and arsenic. J Afr Earth Sci 57(5):479-491. https://doi. org/10.1016/j.jafrearsci.2009.12.005

Rango T, Kravchenko J, Atlaw B, McCornick PG, Jeuland M, Merola B, Vengosh A (2012) Groundwater quality and its health impact: an assessment of dental fluorosis in rural inhabitants of the Main Ethiopian Rift. Environ Int 43:37-47. https://doi.org/10.1016/j. envint.2012.03.002

Rango T, Vengosh A, Jeuland M, Tekle-Haimanot R, Weinthal E, Kravchenko J, McCornick P (2014) Fluoride exposure from groundwater as reflected by urinary fluoride and children's dental fluorosis in the Main Ethiopian Rift Valley. Sci Total Environ 496:188-197. https://doi.org/10.1016/j.scitotenv.2014. 07.048

Rango T, Vengosh A, Jeuland M, Whitford GM, Tekle-Haimanot R (2017) Biomarkers of chronic fluoride exposure in groundwater in a highly exposed population. Sci Total Environ 596:1-11. https://doi.org/10.1016/j.scitotenv.2017.04.021

Rashid A, Guan DX, Farooqi A, Khan S, Zahir S, Jehan S, Khattak SA, Khan MS, Khan R (2018) Fluoride prevalence in groundwater around a fluorite mining area in the flood plain of the River Swat, Pakistan. Sci Total Environ 635:203-215. https://doi.org/10.1016/j.scitotenv.2018.04.064

Reddy DV, Nagabhushanam P, Sukhija BS, Reddy AGS, Smedley PL (2010) Fluoride dynamics in the granitic aquifer of the Wailapally watershed, Nalgonda District, India. Chem Geol 269(3-4):278-289. https://doi.org/10.1016/j.chemgeo.2009.10. 003

Rusiniak P, Ruszczyńska A, Wątor K, Bulska E, Kmiecik E (2020) Methodological aspects concerning sampling and determination of total selenium and selenium species in geothermal waters. Bull Geogr Phys Geogr Ser 18(1):5-16. https://doi.org/10.2478/ bgeo-2020-0001

Saxena V, Ahmed S (2001) Dissolution of fluoride in groundwater: a water-rock interaction study. Environ Geol 40(9):1084-1087. https://doi.org/10.1007/s002540100290

Sekuła K, Rusiniak P, Wator K, Kmiecik E (2020) Hydrogeochemistry and related processes controlling the formation of the chemical composition of thermal water in Podhale Trough, Poland. Energies 13(21):5584

Singh G, Kumari B, Sinam G, Kumar N, Mallick S (2018) Fluoride distribution and contamination in the water, soil and plants continuum and its remedial technologies, an Indian perspectivea review. Environ Pollut 239:95-108. https://doi.org/10.1016/j. envpol.2018.04.002

Smedley PL, Nicolli HB, Macdonald DMJ, Barros AJ, Tullio JO (2002) Hydrogeochemistry of arsenic and other inorganic constituents in groundwaters from La Pampa, Argentina. Appl Geochem 17(3):259-284. https://doi.org/10.1016/S08832927(01)00082-8

Sracek O, Hirata R (2002) Geochemical and stable isotopic evolution of the Guarani Aquifer System in the state of São, Paulo Brazil. Hydrogeol J 10(6):643-655. https://doi.org/10.1007/s10040-0020222-8

Sracek O, Wanke H, Ndakunda NN, Mihaljevič M, Buzek F (2015) Geochemistry and fluoride levels of geothermal springs in Namibia. J Geochem Explor 148:96-104. https://doi.org/10. 1016/j.gexplo.2014.08.012

Sracek O, Geršl M, Faimon J, Bábek O (2019) The geochemistry and origin of fluids in the carbonate structure of the Hranice Karst with the world's deepest flooded cave of the Hranicka Abyss, Czech Republic. Appl Geochem 100:203-212. https://doi.org/ 10.1016/j.apgeochem.2018.11.013

Su H, Wang J, Liu J (2019) Geochemical factors controlling the occurrence of high-fluoride groundwater in the western region of the Ordos basin, northwestern China. Environ Pollut 252:1154-1162. https://doi.org/10.1016/j.envpol.2019.06.046

Tekle-Haimanot R, Melaku Z, Kloos H, Reimann C, Fantaye W, Zerihun L, Bjorvatn K (2006) The geographic distribution of fluoride in surface and groundwater in Ethiopia with an emphasis on the Rift Valley. Sci Total Environ 367(1):182-190. https:// doi.org/10.1016/j.scitotenv.2005.11.003

Tiercelin JJ, Potdevin JL, Morley CK, Talbot MR, Bellon H, Rio A, Le Gall B, Vétel W (2004) Hydrocarbon potential of the MesoCenozoic Turkana Depression, northern Kenya. I. Reservoirs: depositional environments diagenetic characteristics, and source rock-reservoir relationships. Mar Petrol Geol 21(1):41-62. https://doi.org/10.1016/j.marpetgeo.2003.11.007

Tomaszewska B, Rajca M, Kmiecik E, Bodzek M, Bujakowski W, Tyszer M, Wator K (2017) Process of geothermal water treatment by reverse osmosis. The research with antiscalants. Desalin Water Treat 73:1-10

Tomaszewska B, Kmiecik E, Wątor K, Tyszer M (2018) Use of numerical modelling in the prediction of membrane scaling. Reaction between Antiscalants and Feedwater. Desalination 427:27-34. https://doi.org/10.1016/j.desal.2017.11.004 
Toran LE, Saunders JA (1999) Modeling alternative paths of chemical evolution of $\mathrm{Na}-\mathrm{HCO}_{3}$-type groundwater near Oak Ridge, Tennessee USA. Hydrogeol J 7(4):355-364. https://doi. org/10.1007/s100400050208

Turkana Drilling Consortium (2008) Environmental Impact Assessment Project Report For Proposed Exploratory Oil And Natural Gas Well drilling Programme in Block 10BB: Turkana South and Turkana Central.

Turkana Drilling Consortium (2010) Project Report for Environmental Impact Assessment of the Proposed Exploratory Well Drilling in Block 10BB: Turkana South and Turkana Central Districts by Africa Oil Kenya BV

Ullah R, Zafar MS, Shahani N (2017) Potential fluoride toxicity from oral medicaments: a review. Iran J Basic Med Sci 20(8):841. https://doi.org/10.22038/IJBMS.2017.9104

Walsh J, Dodson RG (1969) Geology of northern Turkana degree sheets 129 and 10 (No. 82). Geological Survey of Kenya

Wang M, Li X, He WY, Li JX, Zhu YY, Liao YL, Yang JY, Yang XE (2019) Distribution, health risk assessment, and anthropogenic sources of fluoride in farmland soils in phosphate industrial area, southwest China. Environ Pollut 249:423-433. https://doi.org/ 10.1016/j.envpol.2019.03.044

Wątor K, Kmiecik E, Rusiniak P (2018) An influence of research methodology on the results of determination of a chemical composition of curative water. Acta Balneol 60(4):272-276

Wątor K, Kmiecik E, Postawa A, Rusiniak P (2019) A probabilistic approach to assessment of the quality of drinking water. Geologos 25(3):249-254

Wątor K, Dobrzyński D, Sugimori K, Kmiecik E (2020) Redox potential research in the field of balneochemistry: case study on equilibrium approach to bioactive elements in therapeutic waters. Int J Biometeorol. https://doi.org/10.1007/s00484-02001871-7

WHO (2017) Guidelines for drinking-water quality: fourth edition incorporating the first addendum Geneva. World Health Organization; 2017 Licence: CC BY-NC-SA 30 IGO
Wu C, Wu X, Qian C, Zhu G (2018) Hydrogeochemistry and groundwater quality assessment of high fluoride levels in the Yanchi endorheic region northwest China. Appl Geochem 98:404-417. https://doi.org/10.1016/j.apgeochem.2018.10.016

Yadav KK, Kumar S, Pham QB, Gupta N, Rezania S, Kamyab H, Yadav S, Vymazal J, Kumar V, Tri DQ, Talaiekhozani A, Prasad S, Reece LM, Singh N, Maurya PK, Cho J (2019a) Fluoride contamination, health problems and remediation methods in Asian groundwater: a comprehensive review. Ecotox Environ Safe 182:109362. https://doi.org/10.1016/j.ecoenv.2019.06.045

Yadav KK, Kumar V, Gupta N, Kumar S, Rezania S, Singh N (2019b) Human health risk assessment: study of a population exposed to fluoride through groundwater of Agra city, India. Regul Toxicol Pharm 106:68-80. https://doi.org/10.1016/j.yrtph.2019.04.013

Yuretich RF, Cerling TE (1983) Hydrogeochemistry of Lake Turkana, Kenya: mass balance and mineral reactions in an alkaline lake. Geochim Cosmochim Ac 47(6):1099-1109. https://doi.org/10.1016/0016-7037(83)90240-5

Zango MS, Sunkari ED, Abu M, Lermi A (2019) Hydrogeochemical controls and human health risk assessment of groundwater fluoride and boron in the semi-arid northeastern region of Ghana. J Geochem Explor 207:106363. https://doi.org/10.1016/j.gexplo. 2019.106363

Zevenbergen C, Van Reeuwijk LP, Frapporti G, Louws RJ, Schuiling RD (1996) A simple method for defluoridation of drinking water at village level by adsorption on Ando soil in Kenya. Sci Total Environ 188(2-3):225-232. https://doi.org/10.1016/00489697(96)05174-1

Zhang LE, Huang D, Yang J, Wei X, Qin J, Ou S, Zhang Z, Zou Y (2017) Probabilistic risk assessment of Chinese residents' exposure to fluoride in improved drinking water in endemic fluorosis areas. Environ Pollut 222:118-125. https://doi.org/10. 1016/j.envpol.2016.12.074 